\title{
Bombesin-Like, Substance $P$ and Vasoactive Intestinal Polypeptide Receptors in Fetal Cortical Homografts to Host Cortex and Spinal Cord
}

\author{
Terry W. Moody ${ }^{1}$, Reina L. Getz ${ }^{1}$, William J. Goldberg ${ }^{2,4}$, and Jerald J. Bernstein ${ }^{2,3,4}$ \\ Departments of Biochemistry ${ }^{1}$, Physiology ${ }^{2}$ and Neurosurgery ${ }^{3}$, The George Washington University School \\ of Medicine and Health Sciences, Washington, D.C. 20037 and Laboratory of Central Nervous System \\ Injury and Regeneration ${ }^{4}$, Veterans Administration Medical Center, Washington, D.C. 20422
}

\begin{abstract}
Neuropeptide receptors were visualized in homografts of fetal cortex (E14) into adult rat cortex (immediate or 7 day delay) and spinal cord using in vitro autoradiographic techniques to explore the expression of peptide receptors in the same graft tissue in different central nervous system implantation sites. Receptors for bombesin $(\mathrm{BN})$-like peptides developed in the grafts by 3 weeks postimplantation regardless of location or age of implantation pocket in host. After 4 weeks, the density of $\mathrm{BN}$ receptors was confined to the graft. In grafts to spinal cord, however, high densities of $\mathrm{BN}$-like receptors were not confined to the graft but were distributed throughout the spinal cord. In contrast, the density of vasoactive intestinal polypeptide (VIP) and substance $P$ (SP) receptors was moderate and low to undetectable in the fetal grafts. The development of the peptide receptors studied was graft donor tissue specific since they were not altered by central nervous system implantation site.
\end{abstract}

Reprint address:

Dr. T. Moody

Dept. of Biochemistry

George Washington School of Medicine

Washington, DC 20037, USA

\section{KEY WORDS}

Neural graft, neuropeptide receptors, bombesinlike peptides, vasoactive intestinal polypeptide, substance $P$, regeneration.

\section{INTRODUCTION}

Grafting of fetal central nervous system (CNS) into the nervous system of adult animals has been utilized to study the development of the nervous system both morphologically and chemically $/ 3,5,6 /$. Part of the ontogeny of neural grafts was the development of neurotransmitter and peptide production. For example, transmitters such as dopamine were present in substantia nigra grafts into the denervated striatum $15 /$, whereas septal grafts produced acetylcholine $/ 6 /$. Neuropeptides such as somatostatin /2/ and VIP /9/, but not substance $\mathrm{P} / 8 /$, were produced in rat fetal cortex grafts. Similarly, VIP, cholecystokinin (CCK), somatostatin and pancreatic polypeptide were present in mouse field cortex grafts to cortex $/ 16 /$.

Recently, it was demonstrated that $\beta_{1}$ and $\beta_{2}$ adrenergic receptors but not $D_{2}$ dopaminergic receptors were present in striatal grafts into kainic acid-lesioned rats /11-14/. However, similar studies on the presence of peptide transmitter receptors on fetal grafts are lacking. 
The present experiments will determine the presence and distribution of receptors for substance P, VIP, and bombesin in cortical and spinal neural grafts of the same fetal donor tissue (E14 cortex). These receptors were selected because of the expected development of the peptide in the grafted fetal tissue and the growth stimulating characteristics of these peptides in the central nervous system (CNS). SP has been shown to stimulate neuronal neurite extension /15/ and growth of certain endothelial cells /24/, VIP enhanced survival of embryonic spinal cord neurons /7/ and bombesin stimulated the growth of neuroendocrine cells and was associated with rapidly growing tissues $/ 10 /$.

\section{METHODS}

\section{Host}

The hosts were 30 male Sprague-Dawley (350 g) rats. After deep Nembutal anesthesia (50 $\mathrm{mg} / \mathrm{kg}$ ) the animals were mounted in a Kopf stereotactic head holder. For cortical grafts, the skin on the head was incised and the periosteum removed over the bregma. The skull was trephined and the dura exposed. The dura was incised and an implantation pocket was aspirated at the border of the frontal and somatomotor cortex. The maximum depth of the implantation pocket was determined to be down to approximately layer five. The pocket was packed with $0.9 \% \mathrm{NaCl}$ soaked Gelfoam sponge as described previously $/ 23 /$.

For spinal cord grafts (after deep Nembutal anesthesia) the spinal cord under the sixth thoracic vertebra (T6) was exposed (laminectomy) and the dura incised as described previously $/ 20 \%$.

\section{Donor tissue}

Timed-pregnant Sprague-Dawley rat dams were deeply anesthetized with pentobarbital (50 $\mathrm{mg} / \mathrm{kg}$ ) and fetuses were removed by Caesarean section on embryonic day 14 (E14). The fetus was placed in cold $5 \mathrm{mM}$ phosphate-buffered- saline containing $10 \mathrm{mM}$ glucose (PBS-glucose). The fetal cerebral cortex was dissected free (sectioned into $2.0 \mathrm{~mm}^{2}$ pieces for the cortical graft and minced for the spinal cord graft) in PBS-glucose.

\section{Implantation}

Two types of cortical implantation procedures were used. In one, an implantation pocket was aspirated, the cortical pocket packed with Gelfoam for five minutes, the Gelfoam removed and the graft implanted $(\mathrm{N}=8)$. In the other, the aspirated implantation pocket was packed with Gelfoam and the animal closed. Seven days later the Gelfoam was removed from the pocket and the graft implanted $(\mathrm{N}=8)$. For implantation the $2.0 \mathrm{~mm}^{2}$ piece of $\mathrm{E} 14$ fetal cortex was draped over the tips of a jeweler's forceps and placed flat in the implantation pocket. For spinal grafting, minced E14 spinal cord was aspirated into a 50 ul Hamilton syringe and the graft implanted by pressure injection just under the pia between the left dorsal column and dorsal horn. After both surgeries the musculature and/or skin was closed with interrupted sutures and the animal given 0.2 Longicil (penicillin, Ft. Dodge Labs.) i.m. Animals were utilized 1, 2, 3 and 4 weeks after surgery. Animals for morphology were intracardiac perfused with formalin-acetic acid-alcohol and stained with cresyl violet. Control animals had only carrier implanted (PBS-glucose, $\mathrm{N}=6$ ).

\section{Neuropeptide Receptors}

For receptor analysis, the animals were sacrificed and the neuropeptide receptors characterized using in vitro autoradiographic techniques. The brain or spinal cord was removed, frozen and sectioned on an IEC Minotome. Fresh frozen 16 um thick sections were thaw mounted onto cover slips and air dried. For Substance $P$ (SP) and bombesin (BN)-like peptide receptors, the sections were incubated in Kreb's Ringers buffer which contained $100 \mathrm{ug} / \mathrm{ml}$ bacitracin and $0.25 \%$ bovine serum albumin (BSA) plus radio- 
labeled peptide $(0.4 \mathrm{nM})$ at $25^{\circ} \mathrm{C}$ for $45 \mathrm{~min}$. ${ }^{125} \mathrm{I}$-physalaemin was used for SP receptors and $\left({ }^{125} \mathrm{I}_{-\mathrm{Tyr}}{ }^{4}\right) \mathrm{BN}$ for $\mathrm{BN}$ receptors. The use of these probes has been described previously $122,27,28 /$. Free peptide was removed by 2 consecutive washes in buffer at $4^{\circ} \mathrm{C}$ for $4 \mathrm{~min}$. For VIP receptors, the slide mounted tissue was incubated in Kreb's Ringers buffer which contained $1 \%$ BSA and $1 \mathrm{mg} / \mathrm{ml}$ bacitracin with ${ }^{125} \mathrm{I}$ VIP $(0.2 \mathrm{nM})$ for $90 \mathrm{~min}$ at $25^{\circ} \mathrm{C}$ as described previously /26/. Free ${ }^{125}$ I-VIP was removed by 2 consecutive washes in buffer at $25^{\circ} \mathrm{C}$ for $15 \mathrm{~min}$. The tissue mounted slides which contained bound peptide was opposed to LKB ultrafilm for 7 days. The film was developed and the grain densities representing radiolabeled ligand binding quantitated on an Amersham RAS-R1000 Receptor Autoradiography Analysis System.

\section{RESULTS}

\section{Morphology}

There were no discernible morphological differences between the grafts into host cortex implanted in either fresh or 7 day old implantation pockets. At 4 weeks postimplantation, there was a lack of cortical layering and columnation usually observed in the host. The cortical grafts were large and exceeded the size of the original implanted E14 fetal cortex (Fig. 1A). In all cases there was a mesenchymal scar between the host and the graft (Fig. 1B). The graft contained astrocytes, oligodendrocytes and many mature neurons. Some of these neurons appeared to be cortical pyramidal cells (Fig. 1C).

There were few mature neurons and glia in spinal cord grafts at 1 week. The number of differentiated neurons and neuroglia increased from 2-4 weeks days post implantation. By 4 weeks the grafts were large and occupied the dorsal columns bilaterally and areas of the spinal cord appeared to contain suspected graft derived cells.
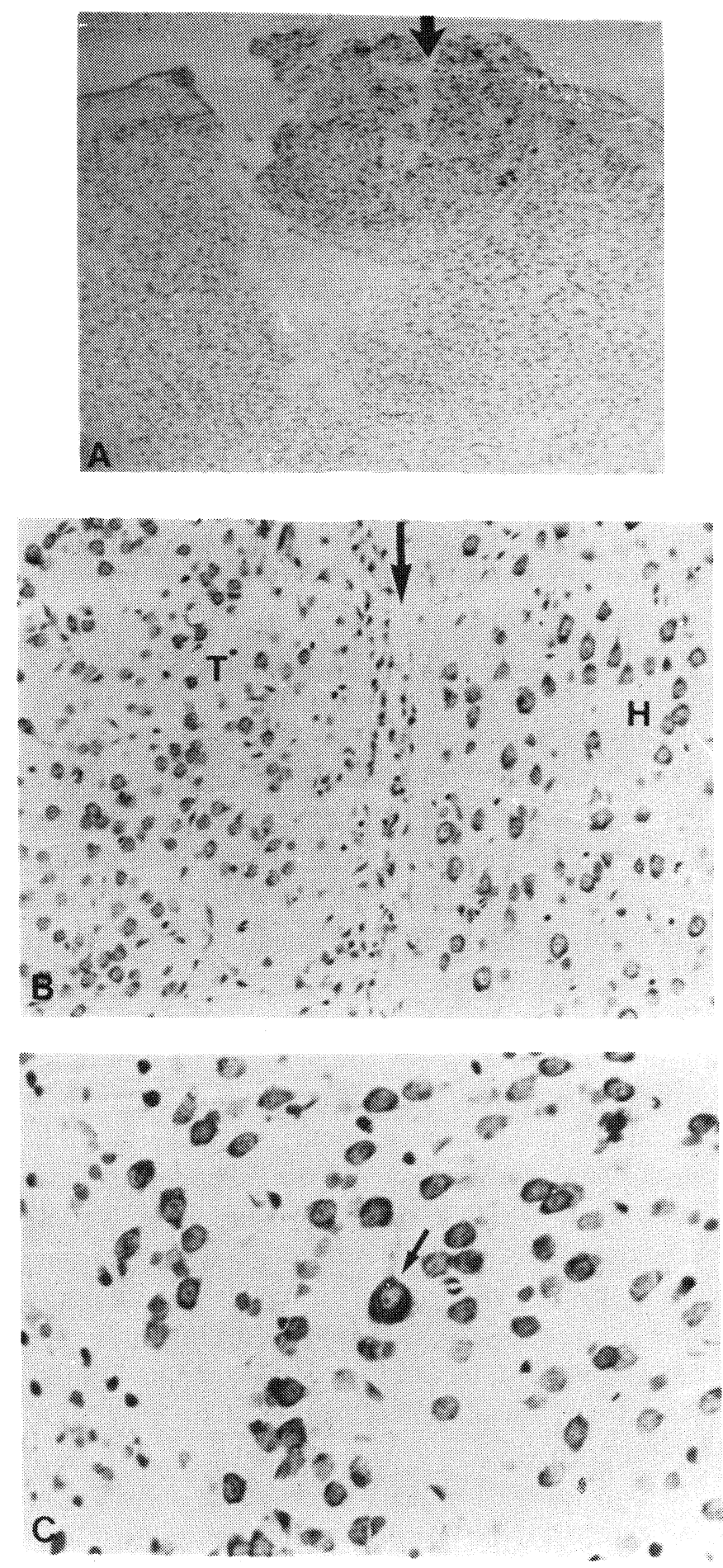

Fig. 1: Cresyl violet stain of a E14 fetal cortex to host cortex graft 4 weeks after immediate transplantation into the implantation pocket. A. Low power micrograph showing the graft (arrow) in the implantation pocket. B. Interface (arrow) between the graft $(T)$ and the host. C. Large pyramidal neuron in the graft (arrow). 


\section{Receptors, donor brain}

The density of receptors for BN-like peptide, SP and VIP, was low in E14 fetal cortex. By densitometry, the concentration of receptors for BNlike peptides using $1 \mathrm{nM}\left({ }^{125} \mathrm{I}-\mathrm{Tyr}^{4}\right) \mathrm{BN}$ was 5 $\mathrm{fmol} / \mathrm{mg}$ protein in E14 parietal cortex.

\section{Receptors, grafted host brain}

In normal adult cortex there were low densities of BN-like peptide and SP receptors and moderate densities of VIP receptors. The distribution of these receptors in cortex was unchanged by the presence of the fetal graft regardless of the age of the implantation pocket (Figs. 2A-C). As in normal brain, grafted brain contained a moderate density of BN-like receptors in the nucleus accumbens, olfactory tubercle, septohippocampal nucleus and basal caudate putamen of the adult host brain following implantation. There was also a low density of these receptors in the neocortex, cingulate and parietal cortex. The corpus callosum was devoid of BNlike receptors.

As in normal brain, grafted brain had a moderate density of SP receptors in the host caudate putamen, nucleus accumbens, olfactory tubercle and rhinal cortex (Fig. 2B). SP receptors were present at a low density, however, in the lateral septal nucleus, parietal and cingulate cortex and were absent from the corpus callosum and anterior commissure as in normal adult brain. No receptors were detected in control sections treated with $1 \mathrm{uM}$ unlabeled substance $\mathrm{P}$ or fetal graft donor cortex.

As in normal brain VIP receptor density was moderate in the grafted cortex, caudate putamen, olfactory tubercle and nucleus accumbens of the host. VIP receptors were not present in the lateral septal nucleus, corpus callosum or anterior commissure as in normal adult brain. Grains were absent in controls treated with $1 \mathrm{uM}$ unlabeled VIP.

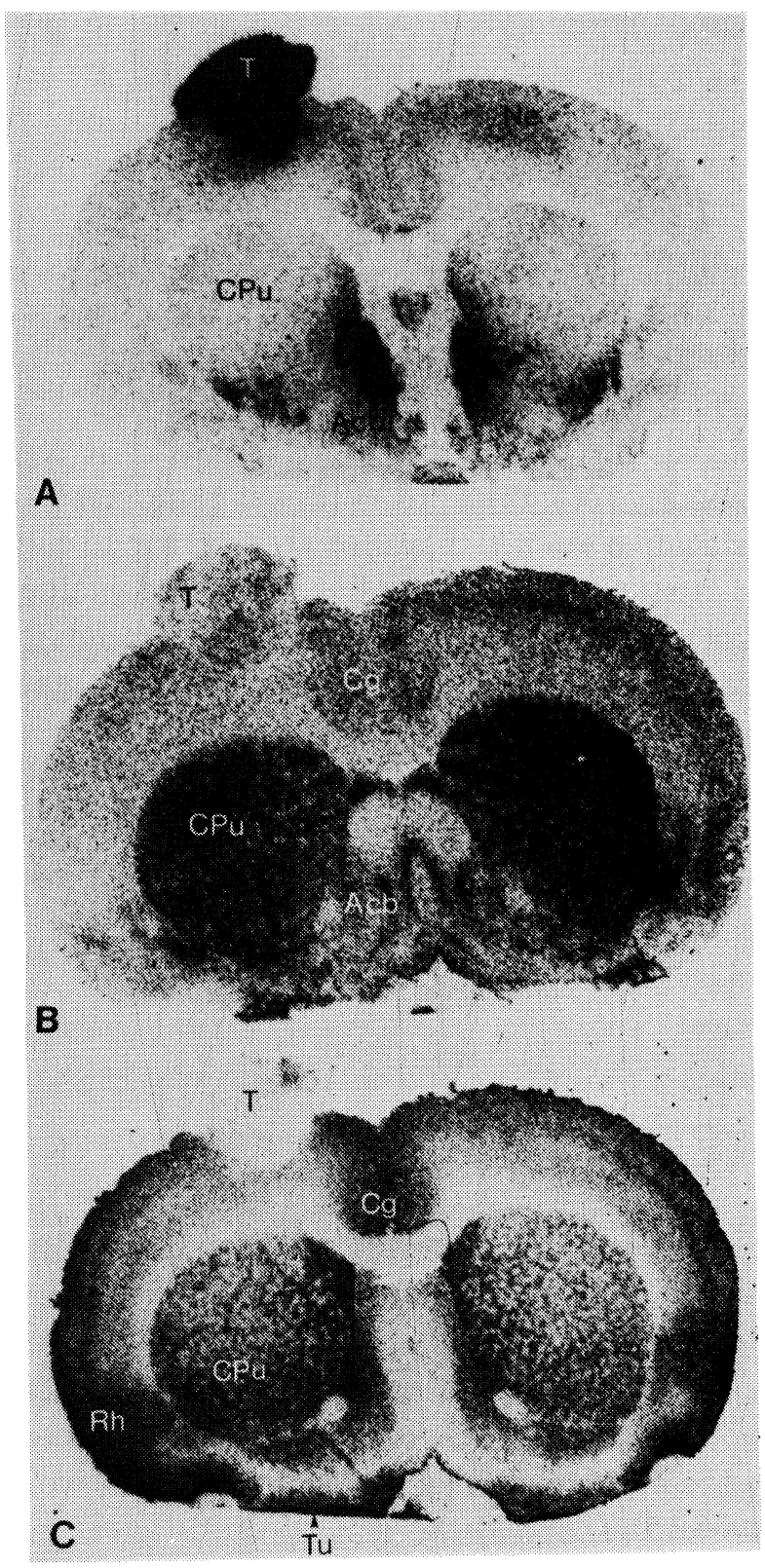

Fig. 2: A. Autoradiographs of receptors for BN-like peptides 4 weeks after implantation of fetal rat cortex in adult rat cortex (level depicted, Paxinos and Watson /25/, coordinates $10.2 \mathrm{~mm}$, interaural). B. Autoradiography of substance $P$ receptors 4 weeks after implantation of fetal rat cortex in rat cortex (10.2 mm, interaural). C. Autoradiography of VIP receptors 4 weeks after implantation of fetal rat cortex in rat cortex (10.2 mm, interaural). Abbreviations Acb, nucleus accumbens; $\mathrm{CPu}$, caudate putamen; Cg, Cingulate cortex; Ne, neocortex; Rh, Rhinal cortex; T, graft; and Tu, olfactory tubercle. 
Receptors, graft in brain

Regardless of the age of the implantation pocket, a high density of receptors for $\mathrm{BN}$-like peptides developed between 2 and 3 weeks in the fetal cortical graft and at 4 weeks far exceeded the density of receptors normally present in adult rat cortex (Fig. 2A). By densitometry, the grain density in the fetal cortical graft tissue (30 fmol/mg protein using $1 \mathrm{nM}\left({ }^{125} \mathrm{I}_{-\mathrm{Tyr}}{ }^{4}\right) \mathrm{BN}$ ) was approximately $50 \%$ greater than in the host nucleus accumbens ( $16 \mathrm{fmol} / \mathrm{mg}$ protein) and 4 fold greater than in the host or normal parietal cortex $\left(7 \mathrm{fmol} / \mathrm{mg}\right.$ protein). Binding of $\left({ }^{125} \mathrm{I}\right.$ $\left.\mathrm{Tyr}^{4}\right) \mathrm{BN}$ was absent in control sections treated with $1 \mathrm{uM}$ unlabeled $\mathrm{BN}$.

SP receptors were not detectable in the fetal cortex graft tissue.

VIP receptors developed between 2 and 3 weeks and were generally present in low concentration in the fetal cortex graft. However, there were small patches of cells containing moderate densities of these receptors in the graft. The grain densities representing the receptors were 2-fold greater in layer I of the normal host cortex than in the densest area of the graft (Fig. 2C).

\section{Receptors, graft in spinal cord}

To ascertain if receptor development was a function of the grafted tissue or the site of implantation, fetal cortical grafts were also implanted into the adult rat spinal cord (Fig. 3AD). In the normal spinal cord there was a high density of receptors for $\mathrm{BN}$-like peptides and SP and a low density of VIP receptors which were confined to Rexed lamina 2 (Fig. 3A,B) of the normal dorsal horn.

Two weeks after grafting no receptors were present within the fetal graft. Receptors for BNlike peptides were found, however, in their normal location in Rexed lamina 2 (Fig. 3B). Although there were no detectable receptors for BN-like peptides in the graft at 2 weeks, the density of receptors increased to a very high level at 3 and 4 weeks postimplantation (Fig. 3C,D). At 4 weeks, there was a massive increase in the den- sity of BN-like receptors within the graft and throughout the spinal cord. The high density and extensive distribution of silver grains representing these receptors obliterated the morphology of the spinal cord (Fig. 4D). This increase in receptor density also obscured the receptors that are normally observed in Rexed lamina 2 . In animals receiving an implantation lesion but no graft, BN-like receptors were only observed in their normal location in Rexed lamina 2.

At 2-3 weeks a moderate density of VIP and a low density of SP receptors developed in the fetal cortical grafts to spinal cord and was unchanged at 4 weeks after implantation. In cross sections of spinal cord these receptors appeared to be confined to the dorsal columns. The distribution of these receptors was densitometrically similar to their distribution in grafts to the cortex.

\section{DISCUSSION}

These data show that specific receptors for peptides developed in fetal cortical homografts into adult host cortex (after delayed or immediate implantation) and spinal cord. Receptors for BN-like peptides developed in fetal homografts between 2 and 3 weeks postimplantation and were distributed throughout the graft by 4 weeks. $\mathrm{BN}$ receptors also developed in grafts of fetal cortex /17/ but not in grafts of fetal cerebellum (unpublished observation) implanted in the fourth ventricle. In contrast to the high density of $\mathrm{BN}$-like receptors which develop in cortical homografts, VIP receptors were present in only moderate density and substance $P$ receptors not at all. These findings were consistent with the expression of VIP and substance $P$ receptors in normal cortex /26-28/. These data indicate that the expression of the peptide receptors studied was a property of the grafted donor tissue and not a function of the implantation site.

The extensive distribution of $\mathrm{BN}$ receptors throughout the host spinal cord was indicative of the invasive nature of fetal neural grafts in adult host spinal cord. In contrast, $\mathrm{BN}$-like receptors of grafts to cortex were confined to the graft. The 
distribution of $\mathrm{BN}$-like receptors in the grafts and host cortex and spinal cord were consistent with the findings of continued growth of fetal grafts in adult spinal cord in the adult rat /1/ and the limited growth of fetal grafts in the cortex of

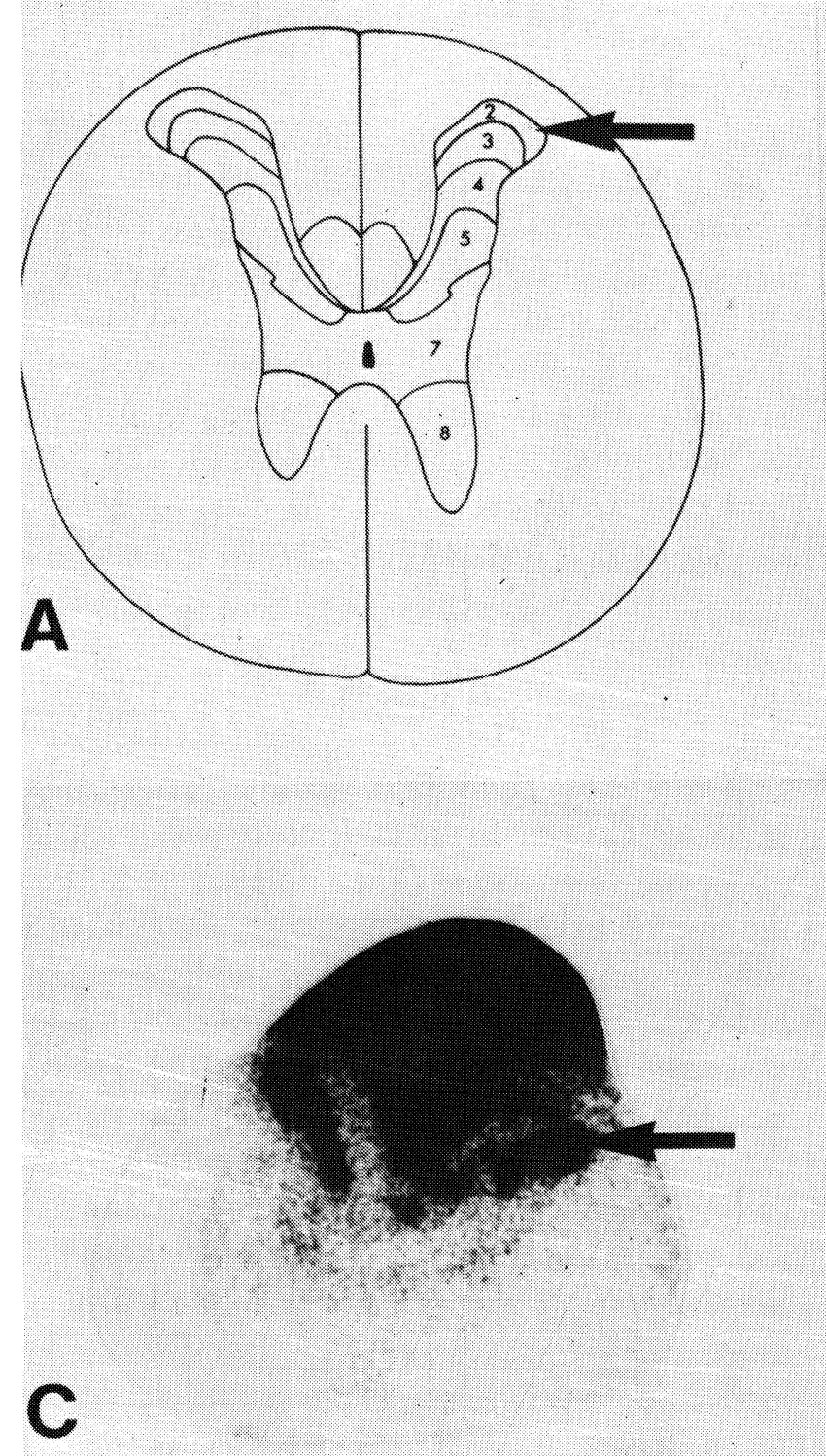

Fig. 3: Autoradiographs of receptors of BN-like peptides for 3 and 4 weeks after implantation of fetal rat cortex between the left dorsal horn and dorsal columns (T6) of rat spinal cord. The arrows represent Rexed Lamina 2. The density of $\left({ }^{125}\right.$ - $\left.-\mathrm{Tyr}^{4}\right) \mathrm{BN}$ binding sites was determined. A. Diagram of T6 spinal cord showing Rexed lamina (modified from 25). B. Normal spinal cord showing that BN-like receptors are confined to Rexed lamina 2. C. At 3 weeks the rats $/ 16 /$. It is known that individual astrocytes migrate from fetal cortical grafts into the host brain $/ 3 /$; however these cells were not observed in the present experiment, probably due to the sensitivity of the method.

\section{B}

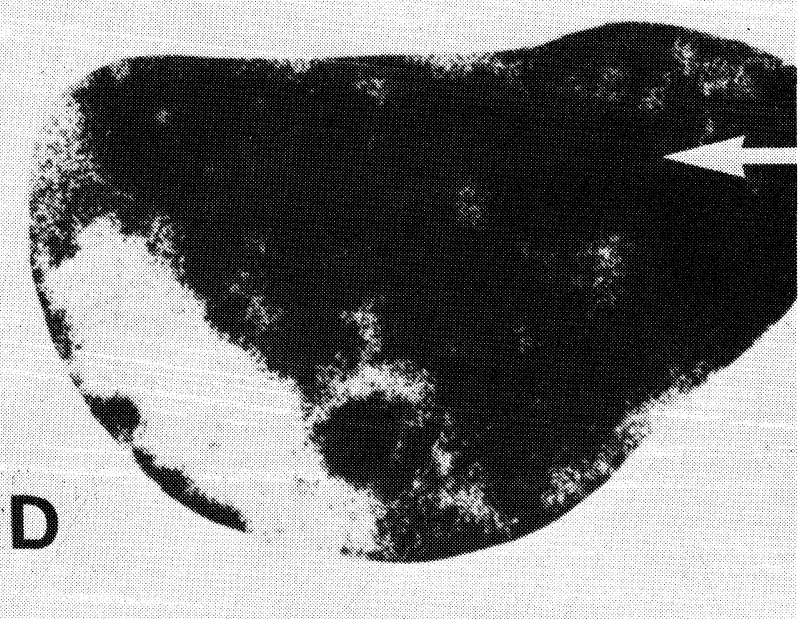

graft had a high density of BN-like receptors. The host spinal cord also shows clusters of BN-like receptors. D. At 4 weeks there was a high density of $\mathrm{BN}$-like receptors throughout the host spinal cord. The morphology of the spinal cord was distorted by the graft and processing and the inner structure is obliterated by the density of silver grains over the tissue. The left lateral column had the least concentration of $\mathrm{BN}$-like receptors. 
While the cells of origin for $\mathrm{BN}$-like receptors remain unknown, it was recently demonstrated that certain human gliomas, which contain rapidly growing transformed astrocytes, had a high density of $\mathrm{BN}$ receptors /21/. The distribution of the grafted cells with BN-like receptors in the host spinal cord in the present experiment suggested that the receptors may also have been on rapidly growing fetal astrocytes. We had previously shown that grafted fetal astrocytes could be labeled with the lectin Phaseolus vulgaris leucoagglutinin (PHAL) and distinguished from host cells $/ 3,4,18-20 /$. Although these fetal neural grafts were placed unilaterally in the spinal cord of adult rats, graft derived fetal astrocytes migrated bilaterally throughout the host spinal cord 13/. In addition, neurons did not migrate any appreciable distance. The distribution of PHAL labeled fetal astrocytes in the spinal cord of adult rats was similar to the distribution of $\mathrm{BN}$-like receptors in the present experiment using the same grafting technique.

The fetal grafts do not appear to have any nerve fibers or perikarya which stain for immunoreactive BN-like peptides (J. Bernstein, unpublished results). This is not surprising as the density of immunoreactive $\mathrm{BN}$ in the adult rat cortex is exceedingly low $/ 22 /$. BN-like peptides, neuromedin $\mathrm{C}$ in particular, are abundant in the dorsal horn of the adult rat spinal cord /22/. Previously we demonstrated that $\mathrm{BN}$-like peptides may be released from the rat spinal cord by depolarizing stimuli /22/ and that these peptides may diffuse and activate receptors present in the fetal graft tissue. Similarly, the fetal grafts in cortex may be activated by $\mathrm{BN}$-like peptides which diffuse to the graft tissue after release from neurons present in the host.

Few, if any, SP receptors were present or developed in fetal cortical grafts to host spinal cord or brain. This was consistent with the normal development of these peptide receptors in normal cortex $/ 27 /$.

A moderate density of VIP receptors was present in grafts in the host cortex. This included small discrete patches of high density of receptors in the grafted fetal cortical tissue. Since VIP receptors were normally present in layer I of the host cortex /26/, the high density patches of these receptors in the grafts could represent the development of cortical layer I cells in the graft.

Receptors for VIP and BN-like peptides, but not substance $P$, were present or developed in rat fetal cortex grafts. The widespread distribution of BN-like receptors in grafted spinal cord and the graft confined distribution in host cortex indicate that the $\mathrm{BN}$-like peptide receptor may be an index of the extent of invasion of fetal grafts in host tissue. The development of the peptide receptors studied was graft donor tissue specific since they were not altered by central nervous system implantation site.

\section{ACKNOWLEDGEMENTS}

This research is supported by NSF grant BNS 8815133 to T.M. and the Veterans Administration to J.B.

\section{REFERENCES}

1. Bernstein JJ. Ependyma formation in adult rat spinal cord after transplantation of fetal cerebral cortex. $J$ Neurosci Res 1986; 15: 481-490.

2. Bernstein JJ, Connor J. Somatostatin-like neurons are expressed in fetal cortical homografts into the spinal cord of the adult rat. Brain Res 1986; 374: 147152.

3. Bernstein JJ, Goldberg WJ. Rapid migration of grafted cortical astrocytes from suspension grafts placed in host thoracic spinal cord. Brain Res 1989; 491: 205-211.

4. Bernstein JJ, Goldberg WJ. Fetal spinal cord homografts ameliorate the severity of lesion induced hind limb behavioral deficits. Exp Neurol 1988; 98: 633644.

5. Bjorklund A, Stenevi U. In: Neural Grafting in the Mammalian CNS. Amsterdam: Elsevier Press, 1985; 709 pp.

6. Bjorklund A, Stenevi U. Regeneration of monoaminergic and cholinergic neurons in the mammalian central nervous system. Physiol Reviews 1979; 59: 62100.

7. Brenneman D, Eiden L. Vasoactive intestinal peptide and electrical activity influence neuronal survival. Proc Natl Acad Sci USA 1986; 85: 1159-1162.

8. Connor J, Bernstein JJ. Expression of peptides and transmitters in neurons and expression of filament 
proteins in astrocytes in fetal cerebral cortical transplants to adult spinal cord. In: Seil F, Herbert E, Carlson B (eds.), Neural Regeneration. Amsterdam: Elsevier Press, 1987; pp. 359-372.

9. Connor J, Bernstein JJ. Vasoactive intestinal polypeptide neurons in fetal cortical homografts to adult rat spinal cord. Brain Res 1986; 367: 214-221.

10. Cuttitta F, Carney D, Milshine J, Moody TW, Fedorko J, Fischler A, Minna J. Bombesin-like peptides can function as autocrine growth factors in human small cell lung cancer. Nature 1985; 316: 823-826.

11. Deckel A, Robinson R. Receptor characteristics and behavioral consequences of kainic acid lesions and fetal transplants of the striatum. Ann NY Acad Sci 1987; 495: 556-580.

12. Deckel A, Moran T, Robinson R. Receptor characteristics and recovery of function following kainic acid lesions and fetal transplants of the striatum. I. Cholinergic systems. Brain Res 1988; 474: 27-38.

13. Deckel A, Moran T, Robinson R. Receptor characteristics and recovery of function following kainic acid lesions and fetal transplants of the striatum. II. Dopaminergic systems. Brain Res 1988; 474: 39-47.

14. Deckel A, Moran T, Saad K, Robinson R. $\beta$-adrenoceptor density in fetal striatal transplants. Eur J Pharmacol 1986; 123: 469-470.

15. Decker A, Gispen W, de Wied D. Axonal regeneration, growth factors and neuropeptides. Life Sci 4978; 41: 1667-1678.

16. Ebner F, Olschowka J, Jacobowitz D. The development of peptide-containing neurons within neocortical transplants in adult mice. Peptides 1984; 5: 103113.

17. Getz R, Moody TW, Rosenstein J. Neuropeptide receptors are present in fetal cortex transplants. Neurosci Lett 1987; 79: 97-102.

18. Goldberg WJ, Bernstein JJ. Fetal cortical astrocytes migrate from cortical homografts throughout the host brain. J Neurosci Res 1989; 20: 38-45.
19. Goldberg WJ, Bernstein JJ. Migration of cultured fetal spinal cord astrocytes into adult host cervical cord and medulla following transplantation into thoracic spinal cord. J Neurosci Res 1988; 19: 34-42.

20. Goldberg WJ, Bernstein JJ. Transplant derived astrocytes migrate into host lumbar and cervical spinal cord after implantation of E14 fetal cerebral cortex into adult thoracic spinal cord. J Neurosci Res 1987; 17: 391-403.

21. Kris R, Hazan R, Villines J, Moody TW, Schlessinger $J$. Identification of the bombesin receptor on murine and human cells by cross-linking experiments. J Biol Chem 1987; 262: 1215-1220.

22. Moody TW, O'Donohue T, Jacobowitz D. Biochemical localization and characterization of bombesin-like peptides in discrete regions of rat brain. Peptides 1981; 2: 75-81.

23. Nieto-Sampedro M, Manthorpe M, Barbin G, Varon $\mathrm{S}$, Cotman CW. Injury-induced neuronotrophic activity in adult rat brain: Correlation with survival of delayed transplants in the wound cavity. J Neurosci 1983; 3: 2219-2229.

24. Nilsson J, Von Euler A, Dalsgaard C. Stimulation of connective tissue cell growth by substance $P$ and substance K. Nature 1985; 315: 61-63.

25. Paxinos G, Watson C. The Rat Brain in Stereotaxic Coordinates. Sydney: Academic Press, 1982.

26. Shaffer M, Moody TW. Autoradiographic visualization of CNS receptors for vasoactive intestinal peptide. Peptides 1986; 7: 283-288.

27. Wolf S, Moody TW, Quirion R, O'Donohue T. Biochemical characterization and autoradiographic localization of central substance $P$ receptors using $\left[{ }^{125} \mathrm{I}\right]$-physalaemin. Brain Res 1985; 332: 299-307.

28. Zarbin M, Kuhar M, O'Donohue T, Wolf S, Moody TW. Autoradiographic localization of $\left[{ }^{125} \mathrm{I}-\right.$ $\mathrm{Tyr}^{4}$ ]bombesin binding sites in rat brain. J Neurosci 1985; 5: 429-437. 

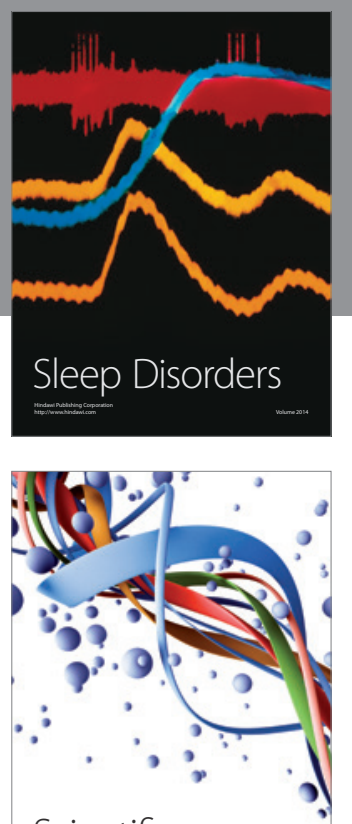

Scientifica
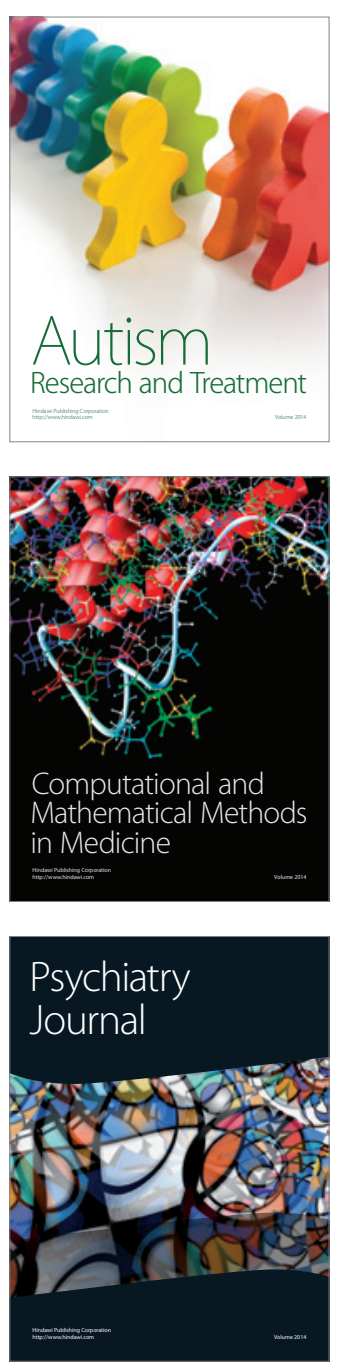
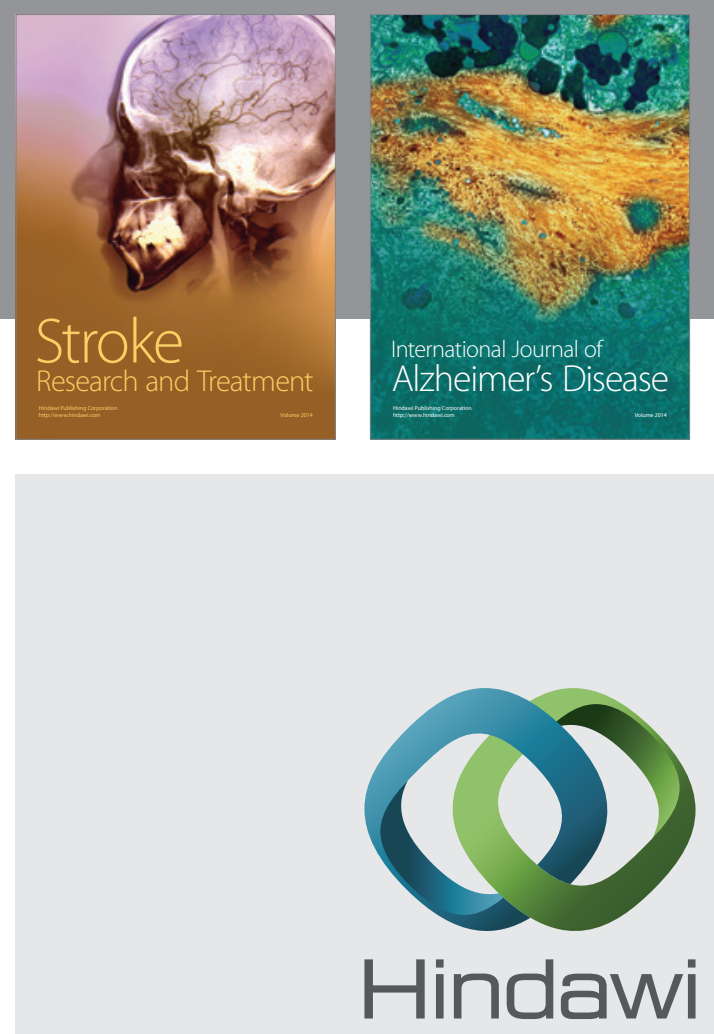

Submit your manuscripts at

http://www.hindawi.com
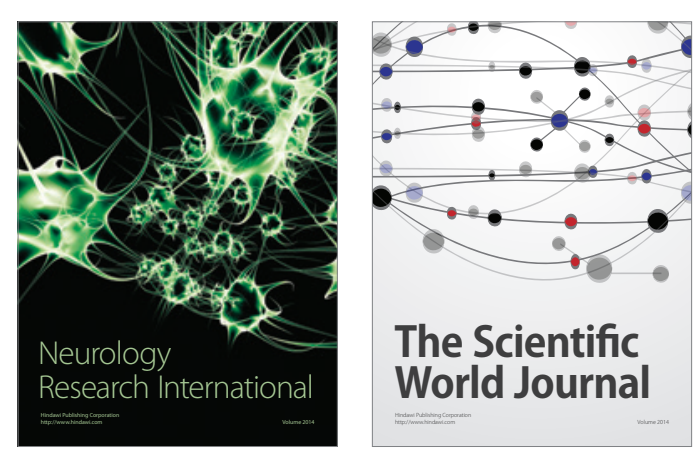

The Scientific World Journal

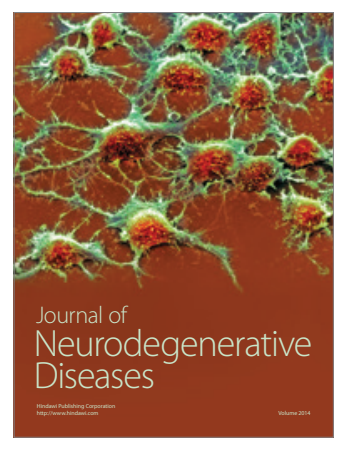

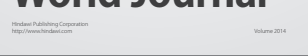

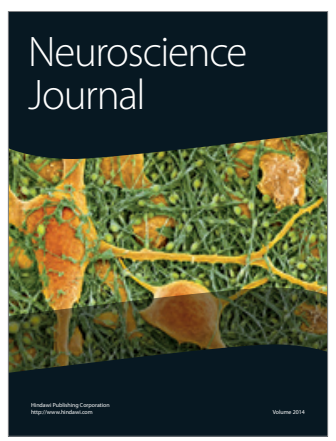

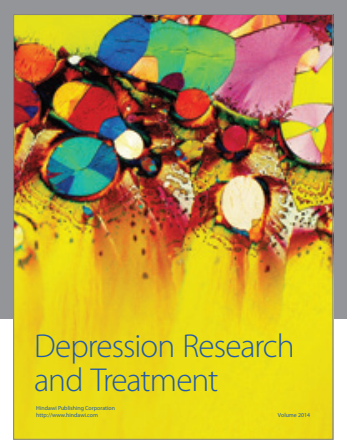
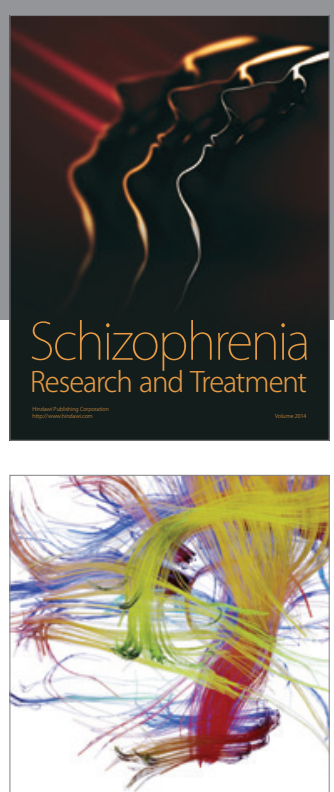

Brain Science

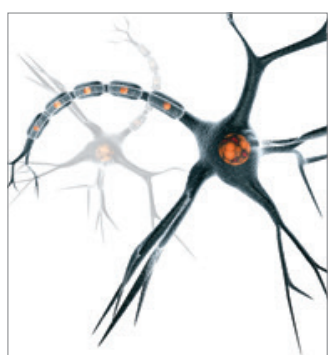

Neural Plasticity
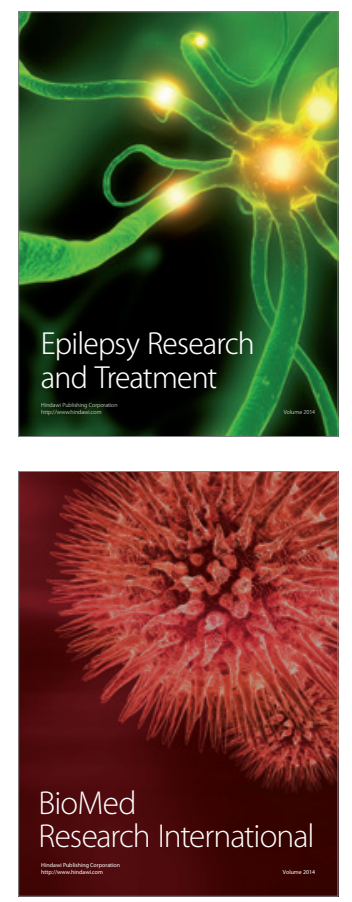

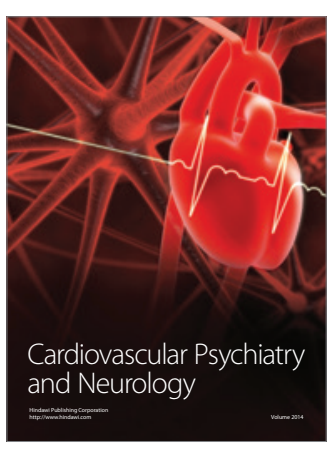

Parkinson's

Disease
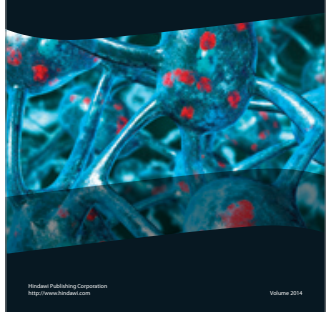